\title{
Responsibilities of Students in Higher Education during the COVID-19 Pandemic and New Normal period
}

\author{
Ezra Taril)* Elisabet Selfina $^{2)}$ Queency Christie Wauran ${ }^{3)}$ \\ 1) Institut Agama Kristen Negeri Kupang, Indonesia \\ 2) Sekolah Tinggi Filsafat Theologia Jaffray Makassar, Indonesia \\ 3) Sekolah Tinggi Filsafat Theologia Jaffray Makassar, Indonesia \\ *) Correspondent author: ezrataril@gmail.com
}

Received: 10 August 2020/Revised: 10 October 2020/Accepted: 20 October 2020

\begin{abstract}
The COVID-19 pandemic is occurring worldwide, including in Indonesia. This issue is the responsibility of all parties. In this university, ethics is the responsibility of the academic community. This paper describes the actions of students towards themselves, and the surrounding community is facing humanitarian disasters. Literature studies are used to lay down problems and find solutions. Study critical of student responsibility in higher education. They share with others with love. Its activities are sharing masks and food and conducting blood donations. Small actions that have a significant impact on society during the COVID-19 and New Normal pandemic.
\end{abstract}

Keywords: COVID-19, Ethics, Higher Education, New Normal, Responsibility.

\section{Abstrak}

Pandemi COVID-19 terjadi di seluruh dunia, termasuk di Indonesia. Masalah ini menjadi tanggung jawab semua pihak. Di Perguruan tinggi ini, etika menjadi tanggung jawab sivitas akademika. Tulisan ini menjelaskan tentang tindakan mahasiswa terhadap diri sendiri, dan masyarakat sekitar dalam menghadapi bencana kemanusiaan. Studi literature digunakan untuk meletakkan masalah dan mencari solusi. Studi kritis terhadap tanggung jawab mahasiswa di perguruan tinggi. Mereka berbagi dengan orang lain dengan kasih. Kegiatannya adalah berbagi masker dan makanan serta melakukan donor darah. Tindakan kecil yang berdampak signifikan bagi masyarakat selama pandemi COVID-19 dan New Normal.

Kata-kata kunci: COVID-19, Etika, New Normal, Pendidikan Tinggi, Tanggung Jawab

\section{Introduction}

Since the beginning, COVID-19 broke out in Wuhan with lockdown measures to prevent the high spread and has gradually relaxed interventions. Meanwhile, in Indonesia, based on data taken by the 
author on June 12, 2020, it shows that nationally 34,406 were positive, 13,213 recovered, and 2,048 died. ${ }^{1}$ This number is still increasing, and it is not known when it will show a sloping curve. Not only the health impacts. But also, the rapidly changing socio-economic conditions. ${ }^{2}$ COVID-19 impacts the world of education, starting from early childhood education to tertiary institutions.

The impact of COVID-19 for education is to change the education system from offline or face to face to fully online. ${ }^{3}$ Social changes on campus and social distance in the shift in the hostel the way they behave and act. Responsibility for yourself and the community on campus is getting tighter. Social distance, physical distance, staying healthy, staying at home, and working from home, use masks in the campus area and outside.

Higher Education follows government regulations for large-scale social restrictions, including online learning, even in dormitories. The government makes policies and provides a sense of security to the community and makes decisions to maintain public health and safety and public trust. ${ }^{4}$ On the other hand, this offers an opportunity for online-based pedagogy in the future. ${ }^{5}$ The world community must make peace with Covid-19. The world community must make peace with COVID-19. The community responded to COVID-19 as both a challenge and an opportunity. In this case, it also applies to higher education.

When the Indonesian government took a policy of closing all educational institutions and making online learning mandatory, the public welcomed it. Viner et al. argued that policymakers to maintain

\footnotetext{
1 "Gugus Tugas Percepatan Penanganan COVID-19," accessed July 28, 2020, https://covid19.go.id/.

${ }^{2}$ Maria Nicola et al., "The Socio-Economic Implications of the Coronavirus Pandemic (COVID-19): A Review," International Journal of Surgery 78, no. 1 (April 2020): 185-93, https://doi.org/10.1016/j.ijsu.2020.04.018.

${ }^{3}$ Eric Liguori and Christoph Winkler, "From Offline to Online: Challenges and Opportunities for Entrepreneurship Education Following the COVID-19 Pandemic," Entrepreneurship Education and Pedagogy 3, no. 4 (April 4, 2020): 346-51, https://doi.org/10.1177/2515127420916738.

${ }^{4}$ Joseph A. Lewnard and Nathan C. Lo, "Scientific and Ethical Basis for SocialDistancing Interventions against COVID-19," The Lancet Infectious Diseases (Lancet Publishing Group, 2020), https://doi.org/10.1016/S1473-3099(20)30190-0.

5 Joseph Crawford et al., "COVID-19: 20 Countries' Higher Education IntraPeriod Digital Pedagogy Responses," Journal of Applied Learning \& Teaching 3, no. 1 (April 1, 2020): 20, https://doi.org/10.37074/jalt.2020.3.1.7.
} 
distance in the learning process were better than directly closing schools to suppress the spread of COVID-19. ${ }^{6}$

Outbreak Prevention and control must involve citizen awareness of the impact of COVID-19. Everyone is required to wear a mask and maintain social distancing. ${ }^{7}$ The Indonesian government took the ethical decision to close schools and switch online learning because it was not easy to monitor the readiness of distancing and adequate health protocols in schools.

The social distancing requirement presents a challenge for all stakeholders to study online because it works in a situation of time constraints and resource constraints. ${ }^{8}$ The curriculum objective that must be emphasized in online learning is to develop the competence of students. The learning approach has mostly shifted to online. Meanwhile, the consideration for the capacity of internet network facilities is different in each region. The instructional evaluation has difficulty in assessing learners' learning. ${ }^{9}$

The challenge of online learning for students is that they are unprepared for significant changes. ${ }^{10}$ However, this learning crisis represents a new opportunity for collaboration at the international level. Stronger international cooperation will involve governments at various levels, companies, and international public-private partnerships. This pattern can provide solutions and produce goods.

The COVID-19crisis might change the world and the global outlook. The pandemic is teaching many people how education needs to

\footnotetext{
${ }^{6}$ Russell M Viner et al., "School Closure and Management Practices during Coronavirus Outbreaks Including COVID-19: A Rapid Systematic Review," The Lancet Child \& Adolescent Health 4, no. 5 (May 1, 2020): 397-404, https://doi.org/10.1016/S23524642(20)30095-X.

${ }^{7}$ Wei Liu, Xiao Guang Yue, and Paul B. Tchounwou, "Response to the Covid-19 Epidemic: The Chinese Experience and Implications for Other Countries," International Journal of Environmental Research and Public Health 17, no. 7 (April 1, 2020): 2304, https://doi.org/10.3390/IJERPHI7072304.

${ }^{8}$ Wahab Ali, "Online and Remote Learning in Higher Education Institutes: A Necessity in Light of COVID-19 Pandemic," Higher Education Studies 10 (2020): 16, https://doi.org/10.5539/hes.vl0n3pl6.

${ }^{9}$ Michael Cahapay, "Rethinking Education in the New Normal Post-COVID-19 Era: A Curriculum Studies Perspective," 2020, 20, https://doi.org/10.29333/aquademia/8315.

${ }^{10}$ Jeanne Allen, Leonie Rowan, and Parlo Singh, "Teaching and Teacher Education in the Time of COVID-19," Asia-Pacific Journal of Teacher Education (Routledge, May 26, 2020), https://doi.org/10.1080/1359866X.2020.1752051.
} 
change in order to prepare students better. This is a challenge for international education collaboration. ${ }^{11}$ To meet the current needs of local, rural, and remote students, they can still access face-to-face learning and maintain a distance. ${ }^{12}$

This situation challenges education systems around the world and forces educators to turn to overnight online learning. Many institutions and academics have previously been reluctant to change traditional pedagogical approaches but have no choice but to use online learning. ${ }^{13}$ The author reviews the small things that students do that have an impact on their daily lives.

Covid-19 has had a significant impact on the world of education, including the education system in Indonesia. Traditional learning processes that emphasize teacher-student interactions in the classroom and outside the classroom shift to distance learning. ${ }^{14}$ The learning process for areas in the yellow, orange, and red zones, face-to-face learning is prohibited. Schools and colleges in all zones are encouraged to continue studying from home. The context of higher education is in the external context; for example, students are dismissed from campus activities to prevent the spread of Covid-19. The online learning method is undoubtedly a challenge for many universities. ${ }^{15}$ However, students from economically disadvantaged family backgrounds have limited access to the internet. So that teachers can give responsibility to

${ }^{11}$ Hans d'Orville, "COVID-19 Causes Unprecedented Educational Disruption: Is There a Road towards a New Normal?" Prospects, 2020, 1, https://doi.org/10.1007/sll125020-09475-0.

12 Amy E. Seymour-Walsh, Anthony Weber, and Andy Bell, "Pedagogical Foundations to Online Lectures in Health Professions Education," Rural and Remote Health 20, no. 2 (May 1, 2020): 6038, https://doi.org/10.22605/RRH6038.

${ }_{13}$ Shivangi Dhawan, "Online Learning: A Panacea in the Time of COVID-19 Crisis," Journal of Educational Technology Systems 49, no. 1 (June 20, 2020): 17, https://doi.org/10.1177/0047239520934018.

${ }^{14}$ Azmil Abidah et al., "The Impact of Covid-19 to Indonesian Education and Its Relation to the Philosophy of "Merdeka Belajar," Studies in Philosophy of Science and Education 1, no. 1 (2020): 38-49, https://doi.org/10.46627/sipose.vlil.9.

${ }^{15}$ Arifin Saleh and Mujahiddin Mujahiddin, "Challenges and Opportunities for Community Empowerment Practices in Indonesia during the Covid-19 Pandemic through Strengthening the Role of Higher Education," Budapest International Research and Critics Institute (BIRCI-Journal): Humanities and Social Sciences 3, no. 2 (May 8, 2020): 1105-13, https://doi.org/10.33258/birci.v3i2.946. 
students during the COVID-19 outbreak, namely participating in the surrounding environment. ${ }^{16}$

Where the government in Indonesia urges to keep your distance and wear masks. Because wearing a mask is very important to prevent transmission of COVID-19. We use a mask for himself because one of the sources of transmission is coughing or sneezing. ${ }^{17}$ Because of that, the students distributed masks, distributed basic foodstuffs, blood donations, and placed banners. What has been the response of students in higher education? Are they just silent? Or they take action as the responsibility of good and obedient Indonesian citizens with government policies as God's representatives on earth.

\section{Theory}

\section{Ethics and Responsibilities}

Ethics and responsibility are not new phenomena, but recent developments in information technology are advancing their impact. For example, one could argue that individual privacy has never been more threatened. Likewise, the risks of manipulating information, particularly vulnerable populations, place serious responsibilities and responsibilities for data controllers. So, organizations face a dual responsibility not just to act but to act ethically and in a socially responsible manner. ${ }^{18}$ Ethics should not be a matter of choice to be carried out by the company according to its convenience, and ethics also cannot be something that must be reported by top management and followed by company officials and staff. Furthermore, ethical behavior cannot be an object of the display to show the world at large that the company is fulfilling its social obligations. ${ }^{19}{ }^{20}$ However, moral responsi-

${ }^{16}$ Rochyani Lestiyanawati and Arif Widyantoro, "Strategies and Problems Faced by Indonesian Teachers in Conducting E-Learning System During COVID-19 Outbreak," Literature, Linguistics and English Teaching) 2, no. 1 (May 31, 2020): 71-82.

${ }^{17}$ Dina Keumala Sari et al., "Positive Correlation Between General Public Knowledge and Attitudes Regarding COVID-19 Outbreak 1 Month After First Cases Reported in Indonesia," Journal of Community Health, June 24, 2020, 1-8, https://doi.org/10.1007/s10900-020-00866-0.

${ }^{18}$ Albert L Harris et al., "Incorporating Ethics and Social Responsibility in IS Education," Journal of Information System Education 22, no. 3 (2019): 187.

${ }^{19}$ Kh Tomba Singh and M Sanjoy Singh, "Ethics in Corporate Social Responsibility," Jurnal of Business and Management 9, no. 2 (2013): 16-21. 
bility is carried out by non-public organizations; as a result, an unclear focus on ethical responsibility so as not to contribute to or advance society's values. ${ }^{21}$

Professional, ethical, social responsibility work is more efficient or even acceptable. For example, few developed countries in China and developing countries prioritize social responsibility and professional ethics. ${ }^{22}$ Ethics education aims to provide people to make decisions with free will. Therefore, teaching ethics has an important place in education. Students who graduate from the university may be well-educated people in the profession, but that is not enough. ${ }^{23}$ Professional ethics is a guide for teachers in providing quality education and instilling good values among students. ${ }^{24}$ According to J. Ivancevich, P. Lorenzi, S. Skinner, and P. Crosby, there is no specific standard in implementing socially responsible behavior. Social responsibility is seen as an obligation; others see it as reactive and proactive behavior. ${ }^{25}$ There is a growing awareness that institutions are structured to organize existing norms. ${ }^{26}$ The aim is to develop a sound framework for decision-making that respects the fact that multiple values exist. ${ }^{27}$

${ }^{20}$ Maidiantius Tanyid, "Etika dalam Pendidikan: Kajian Etis tentang Krisis Moral Berdampak Pada Pendidikan," Jurnal Jaffray 12, no. 2 (October 2, 2014): 235-50, https://doi.org/10.25278/jj7l.vl2i2.13.

${ }^{21}$ Marianthe Stavridou and Sumon Vangchuay, "Beyond Corporate Social Responsibility-A Human-Centre Approach to Business Ethics in the 2lst Century," ATDF Journal 9, no. 1 (2017): 78, https://doi.org/10.5167/uzh-143841.

${ }_{22}^{2}$ Cene Bavec, "Social Responsibility and Professional Ethics in Management," in Social Responsibility, Professional Ethics, and Management, 2010, 24-27.

${ }^{23}$ Nur Yeliz Gülcan, "Discussing the Importance of Teaching Ethics in Education," in Procedia - Social and Behavioral Sciences, vol. 174, 2015, 2622-25, https://doi.org/10.1016/j.sbspro.2015.01.942.

${ }^{24}$ Karma Sherpa, "Importance of Professional Ethics for Teachers," International Education and Research Journal 4, no. 3 (March 15, 2018): 17.

${ }^{25}$ Michael Fontaine, "Corporate Social Responsibility and Sustainability: The New Bottom Line?" International Journal of Business and Social Science, vol. 4, 2013.

${ }^{26}$ Mridula Goel and Preeti E Ramanathan, "ScienceDirect Business Ethics and Corporate Social Responsibility-Is There a Dividing Line?" Procedia Economics and Finance 11 (2014): 49-59, https://doi.org/10.1016/S2212-5671(14)00175-0.

${ }^{27}$ Nien-Hê Hsieh, "The Responsibilities and Role of Business in Relation to Society: Back to Basics?" Society for Business Ethics Presidential Address 27, no. 2 (2017), https://doi.org/10.1017/beq.2017.8. 
Biblical Perspective about Ethics and Responsibility

Students take this social action voluntarily, although they are in trouble due to the Covid 19 pandemic. Students want to do small things that have a significant impact. This duty is done as part of the responsibility of lightening the burden. Helping to bear burdens allows people who need help in times of pain, distress, and financial difficulties (Gal. 6: 2). As a way of life for adult Christians, they have to bear those who are weaker. This responsibility is an efficient and visible way of the New law (cf. 1 Thes. 5:14). ${ }^{28}$ Christian communities should need each other and collectively to show God's love to people. ${ }^{29}$ In Joshua 1:9, God will go with them, where the most significant promise is God's presence (cf. Exod. 3:12) ${ }^{30}$ Students carry out this activity to reduce public anxiety about Covid 19. Isaiah 41:10 explained that God commands not to worry or turn away in pressure. ${ }^{31}$ Students do this because they have accepted the gospel and know peace (1 Cor. 9:23) so that everyone gets to know the good news by taking real action. ${ }^{32}$

A real-life case that frontline workers offer to serve their fellow citizens even in large numbers at personal expense. ${ }^{33}$ A song that states, we pray that our unity will one day be restored, and they will know that we are Christians because of our love. "The message of the song in John 13:35, "By this everyone will know that you are disciples-my disciples if you love one another." 34

\footnotetext{
28 Bob Utley, Paul's First Letters: Galatians and 1 e 2 Thessalonians (Marshall, Texas: Bible Lesson International, 2013).

${ }^{29}$ James A. Fowler, A Commentary on the Epistle to the Galatians (United Sates of America: CIY Publishing, 2011).

${ }^{30}$ Bob Utley, The Conquest of the Promised Land: Joshua (Marshall, Texas: Bible Lesson International, 2013).

${ }^{31}$ Charles R. Sabo, Isaiah: A Bible Commentary (Pittsburgh, Pennsylvania, Amerika: Dorrance Publishing, 2020).

32 Bob Utley, Paul's Letters to a Troubled Church: 1 \& 2 Corinthians (Marshall, Texas: Bible Lessons International, 2013).

${ }^{33}$ Michael A. Peters, "Love and Social Distancing in the Time of Covid-19: The Philosophy and Literature of Pandemics," Educational Philosophy and Theory (Routledge, 2020), https://doi.org/10.1080/00131857.2020.1750091.

${ }^{34}$ Jonathan Merrit, "Christian Cruelty in the Face of COVID-19," the Atlantic, April 24, 2020, https://www.theatlantic.com/ideas/archive/2020/04/christian-crueltyface-covid-19/610477/.
} 


\section{Lecture Responsibility}

In the teaching process, teachers must be able to combine cognitive and affective students. Before students begin lessons, teachers must maintain the emotions of trust by making students feel them. ${ }^{35}$ When something becomes this personal, it uses information about the person being served to change their response. Teachers must use data about students to change how we teach, how students learn, and our institutional policies and practices. ${ }^{36}$

The teacher's ethical responsibility is the ability to find suitable solutions to a particular situation and display consistent, achievable behavior, and live up to moral values, not just state them. ${ }^{37}$ Collective responsibility is a responsibility that is shared among individuals. ${ }^{38}$ Teachers must plan assignments to develop collaborative skills in various aspects to solve complex problems when solved alone. ${ }^{39}$

There are precise requirements for high-quality and innovative pedagogy at the third level of the institution. Evidence suggests greater alignment with a student-centered approach and an emphasis on core generic skills' universal value. In essence, this dynamic of a new learning environment stems from the interaction between teachers and students and a willingness to give up their traditional roles. ${ }^{40}$

\section{Student Responsibility}

Teachers prepare and motivate themselves to improve their knowledge and skills. The goal is to advance the quality of education. Opportunities to increase the quality of online learning are strongly

${ }^{35}$ Mevlut Gunduz, "Educational Research and Reviews What Are the Teaching Responsibilities of Being a Teacher?" 11, no. 8 (2016): 623-29, https://doi.org/10.5897/ERR2016.2643.

${ }^{36}$ D Patrick Saxon, "Student Responsibility and Self-Directed Learning: An Interview with Christine McPhail," Journal of Developmental Education 36, no. 3 (2013): 17.

${ }^{37}$ Daniela Jeder, "ScienceDirect Teachers' Ethic Responsibilities in the Practice of Education and Training," Procedia-Social and Behavioral Sciences 92 (2013): 432-36, https://doi.org/10.1016/j.sbspro.2013.08.697.

${ }^{38}$ Fani V Lauermann, "Teacher Responsibility: Its Meaning, Measure, and Educational Implication,” 2013.

${ }^{39}$ Jeffrey Carpenter and Jennifer Pease, "Preparing Students to Take Responsibility for Learning: The Role of Non-Curricular Learning Strategies," Journal of Curriculum and Instruction 7 (2013): 38-55, https://doi.org/10.3776/joci.2013.

${ }^{40}$ Alan Mc Cabe and Una O'Connor, "Student-Centred Learning: The Role and Responsibility of the Lecturer," Journal Teaching in Higher Education Critical Perspectives 19, no. 4 (2014): 350-59, https://doi.org/10.1080/13562517.2013.860111. 
supported by teachers, parents, and families, coupled with tools from parties involved in education. ${ }^{41}$ Climate change due to the pandemic has claimed more lives, but it is happening more slowly with people's willingness to take an active role. In contrast, millions of children die every year due to hunger and lack of clean water. ${ }^{42}$ Today's students are more inclined towards face-to-face teaching than online lectures. The administration and the faculty should take the necessary measures to improve the quality of e-learning to aid better learning. ${ }^{43}$

Students' responsibility is given through several learning situations; namely, educational content must be by social challenges while still paying attention to the principles of student-centered learning and social practices that promote the development of a professional culture. ${ }^{44}$ Students in the first year usually show more fulfillment of assignments as study obligations, such as attending lectures, exercises, and seminars, and actively participating in them. In the third year, students already emphasize a more responsible and autonomous role. The determinants that influence start from personal maturity and experience during the study. ${ }^{45}$

There are three basic reasons for treating students as agents of academic change: first, the responsibility to learn makes a person a learner and not a customer. Second, paternalism is not fully practiced, where the number of students outnumbers institutional administrators such as teachers, advisors, and educational administrators. Third,

${ }^{41}$ Zamira Hyseni Duraku and Linda Hoxha, "The Impact of COVID-19 on Education and on the Well-Being of Teachers, Parents, and Students: Challenges Related to Remote (Online) Learning and Opportunities for Advancing the Quality of Education," 2020.

${ }^{42}$ Christoph Stückelberger, "COVID-19 and the Ethical Responsibility of Universities," University World News, April 11, 2020, https://www.universityworldnews.com/post.php?story=20200410080845845.

${ }^{43}$ Sahar Abbasi et al., "Perceptions of Students Regarding E-Learning during Covid-19 at a Private Medical College," Pakistan Journal of Medical Sciences 36, no. COVID19-S4 (2020): S57-61, https://doi.org/10.12669/pjms.36.COVID19-S4.2766.

${ }^{44}$ Larisa P. Lazarevaa and Natalia V. Zavodevkina, "Personal and Professional Responsibilities of Students: Psychological and Pedagogical Factors of Real Opportunities," IEJME — MATHEMATICS EDUCATION 11, no. 5 (2016).

${ }^{45}$ Barbara Steh, Jana Kalin, and Jasna Mažgon, "The Role and Responsibility of Teachers And,” Zbornik Instituta Za Pedagoska Istrazivanja 46, no. 1 (2014): 50-68, https://doi.org/10.2298/ZIPI1401050S. 
institutions have an ethical obligation to share what they think and know about current students based on previous experiences. ${ }^{46}$

Students at the college level can finish being more careful about how they need to acknowledge full obligations regarding their academic performance and recognize that teachers are only one of many tools that make progress. ${ }^{47}$ A sense of loyalty between students and lecturers can be involved in the achievements shown by the institution. Or a wellintentioned attempt to solicit student feedback and move towards a model where learning in tertiary institutions becomes a shared responsibility. ${ }^{48}$

\section{Work Together}

An interprofessional team can support safe, high-quality service and all parties' involvement in innovating the organization. As well as learning the smallest parts of organizational behavior that are complex and challenging and rewarding. ${ }^{49}$ Collaborative strategies as a handy tool for developing professional relationships between teachers and students. Potentially students are tools that provide ongoing feedback to help teachers and students target specific problems about learning and professional relationships. ${ }^{50}$ And conduct a group evaluation with a difficult task and have a clear idea of how to evaluate group work. First, the teacher must decide what needs to be evaluated: the end product, the process, or both. Next, it is necessary to determine who will give the assessments: students, teachers, or both. ${ }^{51}$

${ }^{46}$ John Fritz, "Using Analytics to Nudge Student Responsibility for Learning," New Directions for Higher Education 2017, no. 179 (September 1, 2017): 65-75, https://doi.org/10.1002/he.20244.

${ }^{47}$ Stefanie Hassel and Nathan Ridout, "An Investigation of First-Year Students' and Lecturers' Expectations of University Education," Frontiers in Psychology 8, no. 2218 (2018): 12, https://doi.org/10.3389/fpsyg.2017.02218.

48 Alison Cook-Sather, "From Traditional Accountability to Shared Responsibility: The Benefits and Challenges of Student Consultants Gathering Midcourse Feedback in College Classrooms," n.d.

${ }^{49}$ Lyndon Morley and Angela Cashell, "Continuing Medical Education Collaboration in Health Care," Journal of Medical Imaging and Radiation Sciences 48 (2017): 207-16, https://doi.org/10.1016/j.jmir.2017.02.071.

${ }^{50}$ Jenny Ferrier-Kerr, "Working Together: Collaborative Strategies for Developing Effective Professional Relationships in the Practicum," 2012.

${ }^{51}$ Alison Burke, "Group Work: How to Use Groups Effectively," The Journal of Effective Teaching 11, no. 2 (2011): 87-95. 
Team diversity should be viewed as a strength. This can be seen from the problem-solving techniques that have the potential to produce extraordinary results. ${ }^{52}$ Collaborative learning communities require active and collective discussion to provide a safe environment for teachers. While many schools and systems have a tradition of meetings such as departmental or classroom level meetings, this is different from learning teams. In schools, teachers need to change teaching practices. ${ }^{53}$

\section{Method}

The methodology used is literature review ${ }^{54}$ with data collection techniques sourced from reputable international journal references. A literature review investigates scientific manuscripts, books, and other sources relevant to the problem being studied by providing descriptions, summaries, and critical evaluations. ${ }^{55}$ A literature review is used to evaluate a particular topic. The new concept aims to describe the development of research over time. ${ }^{56}$ Literature is used as the basis and support for the new viewpoints that are found. Identify broad keywords relevant to research. Then the keyword search is narrowed down into sub-subjects then compiled a review. Researchers review more or less the primary literature on sources through widely available databases, for

52 Brennan Bosch and Holly Mansell, "Interprofessional Collaboration in Health Care: Lessons to Be Learned from Competitive Sports," Canadian Pharmacists Journal (Canadian Pharmacists Association, July 25, 2015),

https://doi.org/10.1177/1715163515588106.

53 OECD, "Working and Learning Together: Six Policy Approaches to Support Effective Working Environments in Schools," 2019, https://doi.org/10.1787/b7aaf050-en.

${ }^{54}$ Maria Nicola et al., "The Socio-Economic Implications of the Coronavirus Pandemic (COVID-19): A Review," International Journal of Surgery 78 (June 1, 2020): 18593, https://doi.org/10.1016/j.ijsu.2020.04.018; Harmelia Tulak et al., "The Intercultural Competence in Education Era 4.0: A Learning Strategy for Students of Elementary School in Indonesia," in Proceedings of the Proceedings of the Ist International Conference of Science and Technology in Elementary Education, ICSTEE 2019, 14 September, Makassar, South Sulawesi, Indonesia (Proceedings of the lst International Conference of Science and Technology in Elementary Education, ICSTEE 2019, 14 September, Makassar, South Sulawesi, Indonesia, Makassar, Indonesia: EAI, 2019), https://doi.org/10.4108/eai.14-92019.2289961.

55 Abdullah Ramdhani, Muhammad Ali Ramdhani, and Abdusy Amin, "Writing a Literature Review Research Paper: A Step-by-Step Approach," International Journal of Basic and Applied Science 3, no. 1 (2014): 47-56.

${ }^{56}$ Hannah Snyder, "Literature Review as a Research Methodology: An Overview and Guidelines," Journal of Business Research 104 (2019): 333-39, https://doi.org/10.1016/j.jbusres.2019.07.039. 
example, Web of Science, ScienceDirect, SCOPUS, Google Scholar, ERIC. ${ }^{57}$

Then explained the ethics and responsibilities of students in facing the COVID-19 pandemic and entering the New Normal era. Student response in meeting COVID-19 is to carry out ethical decisions and commit to love others as yourself.

\section{Result and Discussion}

Students respond to government regulations during the COVID-19 pandemic and the new normal period with activities, namely:

\section{Distributing Mask}

Stakeholders do not define clear and efficient communication with the public. An analysis of government communications management shows that the messages were delivered, mostly on a positive note. The media, especially national television, mainly conveyed this. In Spain, three out of four citizens have used television to get information during the pandemic. Television is the medium most used by people. ${ }^{58}$ Health authorities should make every effort to distribute face masks with priority to health caregivers and people most vulnerable to infection, especially those older than 65 years and people with health conditions at risk..$^{59}$ The use of masks throughout society can control COVID-19 by reducing the amount of emission of infected saliva from breathing. ${ }^{60}$

Surgical masks are the best type when using masks to prevent transmission of droplets. Cotton masks can be a last resort for people

\footnotetext{
${ }^{57}$ Bert Van Wee and David Banister, "How to Write a Literature Review Paper?," Transport Reviews 36, no. 2 (March 3, 2016): 278-88, https://doi.org/10.1080/01441647.2015.1065456.

${ }^{58}$ Carlos De Las Heras-Pedrosa, Pablo Sánchez-Núñez, and Jose Peláez, "Sentiment Analysis and Emotion Understanding during the COVID-19 Pandemic in Spain and Its Impact on Digital Ecosystems," International Journal of Environmental Research and Public Health 17 (2020): 5542, https://doi.org/10.3390/ijerphl7155542.

${ }^{59}$ Shuo Feng et al., "Rational Use of Face Masks in the COVID-19 Pandemic," The Lancet Respiratory Medicine 8, no. 5 (2020): 436, https://doi.org/10.1016/S22132600(20)30134-X.

${ }^{60}$ Vincent Chi-Chung Cheng et al., "The Role of Community-Wide Wearing of Face Mask for Control of Coronavirus Disease 2019 (COVID-19) Epidemic Due to SARS-CoV-2," Journal of Infection 81 (2020): 107-14, https://doi.org/10.1016/j.jinf.2020.04.024.
} 
without respiratory symptoms. ${ }^{61}$ There is a concern that wearing a mask might create the wrong sense of security with others. This applies to infection control methods such as social distancing and hand washing. There is no evidence in the field yet that wearing a mask can control infection. ${ }^{62}$ Therefore, students distributed masks to the community around the campus, especially for those in need.

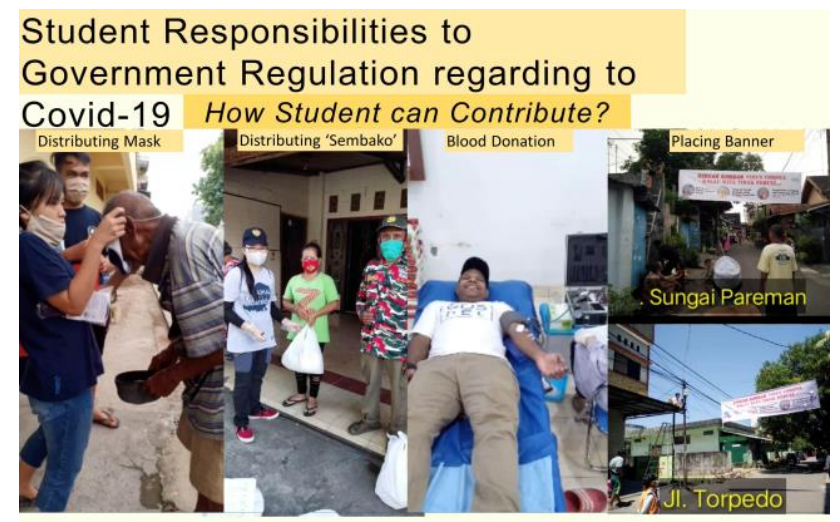

"Small Things can give a significant impact to other"

Figure 1. Student Concern

\section{Distributing Foods}

In the era of the COVID-19 pandemic, the products offered are economically acceptable and competitive and develop foods enriched with antioxidants that improve health and support the immune system. ${ }^{63}$ Planning is needed to rebalance the economy after this crisis. An overall economic development plan, including sector by sector, encourages entrepreneurship so that people have healthy and sustainable business capital. ${ }^{64}$ The government's policy response so far has been

${ }^{61} \mathrm{Mi}-\mathrm{Na}$ Kim, "What Type of Face Mask Is Appropriate for Everyone-MaskWearing Policy amidst COVID-19 Pandemic?," J Korean Med Sci 35, no. 20 (May 2020).

${ }^{62}$ Kar Keung Cheng, Tai Hing Lam, and Chi Chiu Leung, "Wearing Face Masks in the Community during the COVID-19 Pandemic: Altruism and Solidarity," The Lancet 0, no. 0 (2020), https://doi.org/10.1016/S0140-6736(20)30918-1.

${ }^{63}$ Charis M. Galanakis, "The Food Systems in the Era of the Coronavirus (CoVID-19) Pandemic Crisis," Foods (MDPI Multidisciplinary Digital Publishing Institute, April 1, 2020), https://doi.org/10.3390/foods9040523.

${ }^{64}$ Maria Nicola et al., "The Socio-Economic Implications of the Coronavirus Pandemic (COVID-19): A Review," International Journal of Surgery (Elsevier Ltd, June 1, 2020), https://doi.org/10.1016/j.ijsu.2020.04.018. 
aimed at balancing ships by targeting the needs of the poor and those who are potentially low. ${ }^{65}$

The impact of voluntary quarantine on food supply and distribution shows that food distribution is very impactful. ${ }^{66}$ So that students distribute groceries from house to house while still following health protocols, namely wearing masks, washing hands, and keeping your distance. In-store purchases, supermarkets, and markets are unlikely to result in physical distancing. There is a method used, namely, by utilizing online transactions. However, it is necessary to reformulate policies related to food while ensuring food security for disadvantaged communities. $^{67}$

\section{Blood donation}

A range of strategies maintains continuous equitable access to blood transfusions during the pandemic and provides new therapies such as healing plasma. Sharing experiences and developing expert consensus based on evolving publications will assist transfusion services and hospitals in countries at various pandemic stages. ${ }^{68}$ There are five health benefits for donors: improving individual psychological health because it is an expression of love for humans because the blood does not recognize caste, skin color, creed, religion, or race. ${ }^{69}$

Students participate actively in donating blood while still having a complete examination. This scenario was combined with the problem of budgeting for a movement to donate blood voluntarily. This method is used to overcome potential blood shortages. Also, traditional

${ }^{65}$ Susan Olivia, John Gibson, and Rus'an Nasrudin, "Indonesia in the Time of Covid-19," Bulletin of Indonesian Economic Studies 56, no. 2 (May 3, 2020): 143-74, https://doi.org/10.1080/00074918.2020.1798581.

${ }^{66}$ Ali Ekici, Pinar Keskinocak, and Julie Swann, "Modeling Influenza Pandemic and Planning Food Distribution," Manufacturing eamp Service Operations Management 16, no. l (2014): 11-27, https://doi.org/10.1287/msom.2013.0460.

${ }^{67}$ Jasper Grashuis, Theodoros Skevas, and Michelle Segovia, "Grocery Shopping Preferences during the COVID-19 Pandemic," Sustainability 12 (2020): 5369, https://doi.org/10.3390/sul2135369.

68 Simon J. Stanworth et al., "Effects of the COVID-19 Pandemic on Supply and Use of Blood for Transfusion," The Lancet Haematology (Elsevier Ltd, 2020), https://doi.org/10.1016/S2352-3026(20)30186-1.

${ }^{69}$ Dejen Nureye and Eyob Tekalign, "Blood Donations and Blood Banks: A Case on Supply and Demand for Blood in COVID-19 Pandemic," EC Emergency Medicine and Care 4, no. 7 (2020): 1-7. 
communication strategies are still used, such as flayer. ${ }^{70}$ The media can provide information to the public about the safety of donating blood. This will encourage donor participation. Blood collection center organizations should develop a plan for obtaining blood in this postpandemic period while observing health protocols. ${ }^{71}$ How to recruit donors must be designed differently in the new normal. Donors need adequate facilities during the inspection process. ${ }^{72}$

\section{Placing Banner}

Banners were displayed to get responses from the public. Therefore, when building theories about advertising processing on the Internet, perceived entertainment should be able to play an important role in conveying messages to the public. ${ }^{73}$ Temporary segregation of advertising action can be a quality building tool. Momentary behavioral measures, such as clicking on an ad impression, can be used to measure the effectiveness of poor advertising. ${ }^{74}$

The role of advertising messages can be changed to maximize the effectiveness of the messages conveyed through banners. ${ }^{75}$ Given the urgency of the COVID-19 crisis, an important focus is on planning more effective controls to reduce the burden, especially severe cases, and deaths as well as more vulnerable communities. ${ }^{76}$ Students carry out this

${ }^{70}$ Usman Waheed et al., "Effectiveness of WhatsApp for Blood Donor Mobilization Campaigns during COVID-19 Pandemic," ISBT Science Series, 2020, https://doi.org/10.1111/voxs.12572.

${ }^{71}$ Sohail Kumar et al., "Dwindling Blood Reserves: An Ominous Downside of COVID-19 Pandemic," Transfusion and Apheresis Science, 2020, https://doi.org/10.1016/j.transci.2020.102818.

72 Jefferson Rodrigues Pereira et al., "To Donate or Not Donate, That Is the

Question: An Analysis of the Critical Factors of Blood Donation," Ciência $\mho$ Saúde Coletiva 21, no. 8 (2016).

73 Pablo Farías, "The Effect of Advergames, Banners and User Type on the Attitude to Brand and Intention to Purchase," Review of Business Management 20 (2018): 194-209, https://doi.org/10.7819/rbgn.v20i2.3784.

${ }^{74}$ Puneet Manchanda et al., "The Effects of Banner Advertising on Consumer Inter-Purchase Times and Expenditures in Digital Environments," Journal of Marketing Research 43, no. 1 (2006): 98-108, https://doi.org/10.1509/jmkr.43.1.98.

${ }^{75}$ Haren Ghosh and Amit Bhatnagar, "On Measuring and Increasing the Effectiveness of Banner Advertising," MIS Review 19, no. 1 (2013): 25-44, https://doi.org/10.6131/MISR.2013.1901.02.

${ }^{76}$ Daniel Antunes Maciel Villela, "The Value of Mitigating Epidemic Peaks of COVID-19 for More Effective Public Health Responses," Revista Da Sociedade Brasileira de 
activity in response to the government's appeal. The entire communication process must openly integrate risk information, timing and frequency of communication, and strategies at hand. ${ }^{.7}$

The reasonable response is to wear a three-layer non-medical cloth mask inside, adequately filled with tissues, and replaced after 4 hours of use. Wash your hands with soap or hand sanitizer. And keep a minimum distance of 1.5 meters and do not make physical contact. Everyone is encouraged to help others, especially the elderly, the disabled, the poor, and isolated. Take the necessary precautions. By sticking to health protocols and do not risk spreading disease, don't forget the primary Christian duty to help others. "I was sick, and you came to visit me, said Jesus," (Matt. 25).

\section{Conclusion}

The responsibility for oneself is to obey the government to live a healthy, clean environment and follow the WHO standard health protocol. Work from Home, wash hands, and wear masks when going out for urgent and vital needs. Students are responsible for keeping the campus environment clean and staying in line with online learning. The campus also provides free internet to students who live off-campus and have food. Students' responsibility for the campus community is to distribute masks and socialize government regulations, encouraging handwashing and wearing masks. Share with others by helping the economy with food. Students show love to others in the suffering of Covid-19. Students maintain their health so they can donate blood. sehingga students action the COVID-19 community care post and blood donation activities with the Indonesian Red Cross (PMI), a government humanitarian organization, to provide blood for the community.

Medicina Tropical (Sociedade Brasileira de Medicina Tropical, March 23, 2020), https://doi.org/10.1590/0037-8682-0135-2020.

77 Liwei Zhang, Huijie Li, and Kelin Chen, "Effective Risk Communication for Public Health Emergency: Reflection on the COVID-19 (2019-NCoV) Outbreak in Wuhan, China," Healthcare 8, no. 1 (March 21, 2020): 64, https://doi.org/10.3390/healthcare8010064. 


\section{Bibliography}

Abbasi, Sahar, Tahera Ayoob, Abdul Malik, and Shabnam Iqbal Memon. "Perceptions of Students Regarding E-Learning during Covid-19 at a Private Medical College." Pakistan Journal of Medical Sciences 36, no. COVID19-S4 (2020): S57-61. https://doi.org/10.12669/pjms.36.COVID19-S4.2766.

Abidah, Azmil, Hasan Nuurul H, Roy Simamora, Daliana Fehabutar, and Lely Mutakinati. "The Impact of Covid-19 to Indonesian Education and Its Relation to the Philosophy of 'Merdeka Belajar." Studies in Philosophy of Science and Education 1, no. 1 (2020): 38-49. https://doi.org/10.46627/sipose.vlil.9.

Ali, Wahab. "Online and Remote Learning in Higher Education Institutes: A Necessity in Light of COVID-19 Pandemic." Higher Education Studies 10 (2020): 16. https://doi.org/10.5539/hes.vl0n3pl6. Allen, Jeanne, Leonie Rowan, and Parlo Singh. "Teaching and Teacher Education in the Time of COVID-19." Asia-Pacific Journal of Teacher Education. Routledge, May 26, 2020. https://doi.org/10.1080/1359866X.2020.1752051.

Bavec, Cene. "Social Responsibility and Professional Ethics in Management." In Social Responsibility, Professional Ethics, and Management, 24-27, 2010.

Bosch, Brennan, and Holly Mansell. "Interprofessional Collaboration in Health Care: Lessons to Be Learned from Competitive Sports." Canadian Pharmacists Journal. Canadian Pharmacists Association, July 25, 2015. https://doi.org/10.1177/1715163515588106.

Burke, Alison. "Group Work: How to Use Groups Effectively.” The Journal of Effective Teaching 11, no. 2 (2011): 87-95.

Cahapay, Michael. "Rethinking Education in the New Normal PostCOVID-19 Era: A Curriculum Studies Perspective,” 2020, 20. https://doi.org/10.29333/aquademia/8315.

Carpenter, Jeffrey, and Jennifer Pease. "Preparing Students to Take Responsibility for Learning: The Role of Non-Curricular Learning Strategies." Journal of Curriculum and Instruction 7 (2013): 38-55. https://doi.org/10.3776/joci.2013.

Cheng, Kar Keung, Tai Hing Lam, and Chi Chiu Leung. "Wearing Face Masks in the Community during the COVID-19 Pandemic: Altruism and Solidarity." The Lancet 0, no. 0 (2020). https://doi.org/10.1016/S0140-6736(20)30918-1.

Chi-Chung Cheng, Vincent, Shuk-Ching Wong, Vivien Wai-Man Chuang, Simon Yung-Chun So, Jonathan Hon-Kwan Chen, Siddharth Sridhar, Kelvin Kai-Wang To, et al. "The Role of 
Community-Wide Wearing of Face Mask for Control of Coronavirus Disease 2019 (COVID-19) Epidemic Due to SARSCoV-2." Journal of Infection 81 (2020): 107-14. https://doi.org/10.1016/j.jinf.2020.04.024.

Cook-Sather, Alison. "From Traditional Accountability to Shared

Responsibility: The Benefits and Challenges of Student

Consultants Gathering Midcourse Feedback in College Classrooms," n.d.

Crawford, Joseph, Kerryn Butler- Henderson, Jürgen Rudolph, Bashar Malkawi, Matt Glowatz, Rob Burton, Paola A. Magni, and Sophia Lam. "COVID-19: 20 Countries' Higher Education Intra-Period Digital Pedagogy Responses." Journal of Applied Learning \& Teaching 3, no. 1 (April 1, 2020): 20. https://doi.org/10.37074/jalt.2020.3.1.7.

Dhawan, Shivangi. "Online Learning: A Panacea in the Time of COVID19 Crisis." Journal of Educational Technology Systems 49, no. 1 (June 20, 2020): 17. https://doi.org/10.1177/0047239520934018.

d'Orville, Hans. "COVID-19 Causes Unprecedented Educational

Disruption: Is There a Road towards a New Normal?" Prospects, 2020, 1. https://doi.org/10.1007/sll125-020-09475-0.

Ekici, Ali, Pinar Keskinocak, and Julie Swann. "Modeling Influenza

Pandemic and Planning Food Distribution." Manufacturing \&amp Service Operations Management 16, no. 1 (2014): 11-27.

https://doi.org/10.1287/msom.2013.0460.

Farías, Pablo. "The Effect of Advergames, Banners and User Type on the Attitude to Brand and Intention to Purchase." Review of Business Management 20 (2018): 194-209.

https://doi.org/10.7819/rbgn.v20i2.3784.

Feng, Shuo, Chen Shen, Nan Xia, Wei Song, Mengzhen Fan, and Benjamin Cowling. "Rational Use of Face Masks in the COVID-19 Pandemic." The Lancet Respiratory Medicine 8, no. 5 (2020): 436. https://doi.org/10.1016/S2213-2600(20)30134-X.

Ferrier-Kerr, Jenny. "Working Together: Collaborative Strategies for Developing Effective Professional Relationships in the Practicum," 2012.

Fontaine, Michael. "Corporate Social Responsibility and Sustainability: The New Bottom Line?" International Journal of Business and Social Science. Vol. 4, 2013.

Fowler, James A. A Commentary on the Epistle to the Galatians. United Sates of America: CIY Publishing, 2011.

Fritz, John. "Using Analytics to Nudge Student Responsibility for Learning." New Directions for Higher Education 2017, no. 179 (September 1, 2017): 65-75. https://doi.org/10.1002/he.20244. 
Galanakis, Charis M. "The Food Systems in the Era of the Coronavirus (CoVID-19) Pandemic Crisis." Foods. MDPI Multidisciplinary Digital Publishing Institute, April 1, 2020. https://doi.org/10.3390/foods9040523.

Ghosh, Haren, and Amit Bhatnagar. "On Measuring and Increasing the Effectiveness of Banner Advertising." MIS Review 19, no. 1 (2013): 25-44. https://doi.org/10.6131/MISR.2013.1901.02.

Goel, Mridula, and Preeti E Ramanathan. "ScienceDirect Business Ethics and Corporate Social Responsibility-Is There a Dividing Line?" Procedia Economics and Finance 11 (2014): 49-59. https://doi.org/10.1016/S2212-5671(14)00175-0.

Grashuis, Jasper, Theodoros Skevas, and Michelle Segovia. "Grocery Shopping Preferences during the COVID-19 Pandemic." Sustainability 12 (2020): 5369. https://doi.org/10.3390/sul2135369. "Gugus Tugas Percepatan Penanganan COVID-19." Accessed July 28, 2020. https://covidl9.go.id/.

Gülcan, Nur Yeliz. "Discussing the Importance of Teaching Ethics in Education." In Procedia - Social and Behavioral Sciences, 174:2622-25, 2015. https://doi.org/10.1016/j.sbspro.2015.01.942.

Gunduz, Mevlut. "Educational Research and Reviews What Are the Teaching Responsibilities of Being a Teacher?" 11, no. 8 (2016): 623-29. https://doi.org/10.5897/ERR2016.2643.

Harris, Albert L, Michael Lang, Dave Yates, and S E Kruck. "Incorporating Ethics and Social Responsibility in IS Education." Journal of Information System Education 22, no. 3 (2019): 187.

Hassel, Stefanie, and Nathan Ridout. "An Investigation of First-Year Students' and Lecturers' Expectations of University Education." Frontiers in Psychology 8, no. 2218 (2018): 12. https://doi.org/10.3389/fpsyg.2017.02218.

Hsieh, Nien-Hê. "The Responsibilities and Role of Business in Relation to Society: Back to Basics?" Society for Business Ethics Presidential Address 27, no. 2 (2017). https://doi.org/10.1017/beq.2017.8.

Hyseni Duraku, Zamira, and Linda Hoxha. "The Impact of COVID-19 on Education and on the Well-Being of Teachers, Parents, and Students: Challenges Related to Remote (Online) Learning and Opportunities for Advancing the Quality of Education," 2020.

Jeder, Daniela. "ScienceDirect Teachers' Ethic Responsibilities in the Practice of Education and Training." Procedia-Social and Behavioral Sciences 92 (2013): 432-36. https://doi.org/10.1016/j.sbspro.2013.08.697. 
Kim, Mi-Na. "What Type of Face Mask Is Appropriate for EveryoneMask-Wearing Policy amidst COVID-19 Pandemic?" J Korean Med Sci 35, no. 20 (May 2020).

Kumar, Sohail, Dua Azim, Sundus Nasim, and Shariq Haider Hashmi. "Dwindling Blood Reserves: An Ominous Downside of COVID-19 Pandemic." Transfusion and Apheresis Science, 2020. https://doi.org/10.1016/j.transci.2020.102818.

Las Heras-Pedrosa, Carlos De, Pablo Sánchez-Núñez, and Jose Peláez. "Sentiment Analysis and Emotion Understanding during the COVID-19 Pandemic in Spain and Its Impact on Digital Ecosystems." International Journal of Environmental Research and Public Health 17 (2020): 5542. https://doi.org/10.3390/ijerphl7155542.

Lauermann, Fani V. "Teacher Responsibility: Its Meaning, Measure, and Educational Implication," 2013.

Lazarevaa, Larisa P., and Natalia V. Zavodevkina. "Personal and

Professional Responsibilities of Students: Psychological and

Pedagogical Factors of Real Opportunities." IEJME MATHEMATICS EDUCATION 11, no. 5 (2016).

Lestiyanawati, Rochyani, and Arif Widyantoro. "Strategies and Problems

Faced by Indonesian Teachers in Conducting E-Learning System

During COVID-19 Outbreak." Literature, Linguistics and English

Teaching) 2, no. 1 (May 31, 2020): 71-82.

Lewnard, Joseph A., and Nathan C. Lo. "Scientific and Ethical Basis for

Social-Distancing Interventions against COVID-19." The Lancet

Infectious Diseases. Lancet Publishing Group, 2020.

https://doi.org/10.1016/S1473-3099(20)30190-0.

Liguori, Eric, and Christoph Winkler. "From Offline to Online:

Challenges and Opportunities for Entrepreneurship Education Following the COVID-19 Pandemic." Entrepreneurship Education and Pedagogy 3, no. 4 (April 4, 2020): 346-5l. https://doi.org/10.1177/2515127420916738.

Liu, Wei, Xiao Guang Yue, and Paul B. Tchounwou. "Response to the Covid-19 Epidemic: The Chinese Experience and Implications for Other Countries." International Journal of Environmental Research and Public Health 17, no. 7 (April 1, 2020): 2304. https://doi.org/10.3390/IJERPH17072304.

Manchanda, Puneet, Jean-Pierre Dube, Khim Goh, and Pradeep Chintagunta. "The Effects of Banner Advertising on Consumer Inter-Purchase Times and Expenditures in Digital Environments." Journal of Marketing Research 43, no. 1 (2006): 98-108. https://doi.org/10.1509/jmkr.43.1.98. 
Mc Cabe, Alan, and Una O'Connor. "Student-Centred Learning: The Role and Responsibility of the Lecturer." Journal Teaching in Higher Education Critical Perspectives 19, no. 4 (2014): 350-59. https://doi.org/10.1080/13562517.2013.860111.

Merrit, Jonathan. "Christian Cruelty in the Face of COVID-19." the Atlantic, April 24, 2020.

https://www.theatlantic.com/ideas/archive/2020/04/christiancruelty-face-covid-19/610477/.

Morley, Lyndon, and Angela Cashell. "Continuing Medical Education Collaboration in Health Care." Journal of Medical Imaging and Radiation Sciences 48 (2017): 207-16. https://doi.org/10.1016/j.jmir.2017.02.071.

Nicola, Maria, Zaid Alsafi, Catrin Sohrabi, Ahmed Kerwan, Ahmed AlJabir, Christos Iosifidis, Maliha Agha, and Riaz Agha. "The SocioEconomic Implications of the Coronavirus Pandemic (COVID-19): A Review." International Journal of Surgery 78, no. 1 (April 2020): 18593. https://doi.org/10.1016/j.ijsu.2020.04.018. . "The Socio-Economic Implications of the Coronavirus Pandemic (COVID-19): A Review." International Journal of Surgery 78 (June 1, 2020): 185-93. https://doi.org/10.1016/j.ijsu.2020.04.018. . "The Socio-Economic Implications of the Coronavirus Pandemic (COVID-19): A Review." International Journal of Surgery. Elsevier Ltd, June 1, 2020. https://doi.org/10.1016/j.ijsu.2020.04.018.

Nureye, Dejen, and Eyob Tekalign. "Blood Donations and Blood Banks: A Case on Supply and Demand for Blood in COVID-19 Pandemic." EC Emergency Medicine and Care 4, no. 7 (2020): 1-7.

OECD. "Working and Learning Together: Six Policy Approaches to Support Effective Working Environments in Schools," 2019. https://doi.org/10.1787/b7aaf050-en.

Olivia, Susan, John Gibson, and Rus'an Nasrudin. "Indonesia in the Time of Covid-19." Bulletin of Indonesian Economic Studies 56, no. 2 (May 3, 2020): 143-74. https://doi.org/10.1080/00074918.2020.1798581.

Patrick Saxon, D. "Student Responsibility and Self-Directed Learning: An Interview with Christine McPhail." Journal of Developmental Education 36, no. 3 (2013): 17.

Pereira, Jefferson Rodrigues, Caissa Veloso e Sousa, Eliane Bragança de Matos, Leonardo Benedito Oliveira Rezende, Natália Xavier Bueno, and Álvaro Machado Dias. "To Donate or Not Donate, That Is the Question: An Analysis of the Critical Factors of Blood Donation." Ciência e Saúde Coletiva 21, no. 8 (2016).

Peters, Michael A. "Love and Social Distancing in the Time of Covid-19: The Philosophy and Literature of Pandemics." Educational Philosophy 
and Theory. Routledge, 2020.

https://doi.org/10.1080/00131857.2020.1750091.

Ramdhani, Abdullah, Muhammad Ali Ramdhani, and Abdusy Amin.

"Writing a Literature Review Research Paper: A Step-by-Step

Approach." International Journal of Basic and Applied Science 3, no. 1 (2014): 47-56.

Sabo, Charles R. Isaiah: A Bible Commentary. Pittsburgh, Pennsylvania, Amerika: Dorrance Publishing, 2020.

Saleh, Arifin, and Mujahiddin Mujahiddin. "Challenges and Opportunities for Community Empowerment Practices in Indonesia during the Covid-19 Pandemic through Strengthening the Role of Higher Education." Budapest International Research and Critics Institute (BIRCI-Journal): Humanities and Social Sciences 3, no. 2 (May 8, 2020): 1105-13. https://doi.org/10.33258/birci.v3i2.946.

Sari, Dina Keumala, Rina Amelia, Ridha Dharmajaya, Liza Meutia Sari, and Nadya Keumala Fitri. "Positive Correlation Between General Public Knowledge and Attitudes Regarding COVID-19 Outbreak 1 Month After First Cases Reported in Indonesia." Journal of Community Health, June 24, 2020, 1-8. https://doi.org/10.1007/s10900-020-00866-0.

Seymour-Walsh, Amy E., Anthony Weber, and Andy Bell. "Pedagogical Foundations to Online Lectures in Health Professions Education." Rural and Remote Health 20, no. 2 (May 1, 2020): 6038. https://doi.org/10.22605/RRH6038.

Sherpa, Karma. "Importance Of Professional Ethics For Teachers." International Education and Research Journal 4, no. 3 (March 15, 2018): 17.

Singh, Kh Tomba, and M Sanjoy Singh. "Ethics in Corporate Social

Responsibility." Jurnal of Business and Management 9, no. 2 (2013): 1621.

Snyder, Hannah. "Literature Review as a Research Methodology: An Overview and Guidelines." Journal of Business Research 104 (2019): 333-39. https://doi.org/10.1016/j.jbusres.2019.07.039.

Stanworth, Simon J., Helen V. New, Torunn O. Apelseth, Susan Brunskill, Rebecca Cardigan, Carolyn Doree, Marc Germain, et al. "Effects of the COVID-19 Pandemic on Supply and Use of Blood for Transfusion." The Lancet Haematology. Elsevier Ltd, 2020. https://doi.org/10.1016/S2352-3026(20)30186-1.

Stavridou, Marianthe, and Sumon Vangchuay. "Beyond Corporate Social Responsibility-A Human-Centre Approach to Business Ethics in the 2lst Century." ATDF Journal 9, no. 1 (2017): 78. https://doi.org/10.5167/uzh-143841. 
Šteh, Barbara, Jana Kalin, and Jasna Mažgon. "The Role And Responsibility of Teachers And." Zbornik Instituta Za Pedagoska Istrazivanja 46, no. 1 (2014): 50-68. https://doi.org/10.2298/ZIPIl401050S.

Stückelberger, Christoph. "COVID-19 and the Ethical Responsibility of Universities.” University World News, April 11, 2020. https://www.universityworldnews.com/post.php?story=202004100 80845845.

Tanyid, Maidiantius. "Etika dalam Pendidikan: Kajian Etis tentang Krisis Moral Berdampak Pada Pendidikan." Jurnal Jaffray 12, no. 2 (October 2, 2014): 235-50. https://doi.org/10.25278/jj7l.vl2i2.13.

Tulak, Harmelia, Hengki Wijaya, Susanna N. Rante, Nurmadiah Nurmadiah, and Helaluddin Helaluddin. "The Intercultural Competence in Education Era 4.0: A Learning Strategy for Students of Elementary School in Indonesia." In Proceedings of the Proceedings of the 1st International Conference of Science and Technology in Elementary Education, ICSTEE 2019, 14 September, Makassar, South Sulawesi, Indonesia. Makassar, Indonesia: EAI, 2019. https://doi.org/10.4108/eai.14-9-2019.2289961.

Utley, Bob. Paul's First Letters: Galatians and 1 \& 2 Thessalonians. Marshall, Texas: Bible Lesson International, 2013.

. Paul's Letters to a Troubled Church: 1 e 2 Corinthians. Marshall, Texas: Bible Lessons International, 2013.

. The Conquest of the Promised Land: Joshua. Marshall, Texas: Bible Lesson International, 2013.

Villela, Daniel Antunes Maciel. "The Value of Mitigating Epidemic Peaks of COVID-19 for More Effective Public Health Responses." Revista Da Sociedade Brasileira de Medicina Tropical. Sociedade Brasileira de Medicina Tropical, March 23, 2020. https://doi.org/10.1590/00378682-0135-2020.

Viner, Russell M, Simon J Russell, Helen Croker, Jessica Packer, Joseph Ward, Claire Stansfield, Oliver Mytton, Chris Bonell, and Robert Booy. "School Closure and Management Practices during Coronavirus Outbreaks Including COVID-19: A Rapid Systematic Review." The Lancet Child \& Adolescent Health 4, no. 5 (May 1, 2020): 397-404. https://doi.org/10.1016/S2352-4642(20)30095-X.

Waheed, Usman, Akhlaaq Wazeer, Noor Saba, and Zahida Qasim. "Effectiveness of WhatsApp for Blood Donor Mobilization Campaigns during COVID-19 Pandemic." ISBT Science Series, 2020. https://doi.org/10.1111/voxs.12572. 
Wee, Bert Van, and David Banister. "How to Write a Literature Review Paper?" Transport Reviews 36, no. 2 (March 3, 2016): 278-88. https://doi.org/10.1080/01441647.2015.1065456.

Winchester, Catherine L, and Mark Salji. "Writing a Literature Review." Journal of Clinical Urology 9, no. 5 (2016): 308-12.

Zhang, Liwei, Huijie Li, and Kelin Chen. "Effective Risk Communication for Public Health Emergency: Reflection on the COVID-19 (2019NCoV) Outbreak in Wuhan, China." Healthcare 8, no. 1 (March 21, 2020): 1-13. https://doi.org/10.3390/healthcare8010064. 